\title{
Inflation Sources Across Developed And Developing Countries; Panel Approach
}

\author{
Mohammed Al-Sabaey, Public Authority for Applied Education and Training, Kuwait
}

\begin{abstract}
This paper investigates the sources of inflation across a sample of countries in the world. The data set covers around fifty nine countries using yearly data over the period from 1970 through 2007. The model is estimated using a panel model with a random effects specification. Results indicate that the main determinants of inflation for developing countries are different than those for developed countries. Our findings show that the main determinants of inflation for developed countries include government spending, money supply growth, world oil prices, interest rate, nominal effective exchange rate, and population. Whereas, sources of inflation for developing countries are estimated to include government spending, money supply growth, world oil prices, and the nominal effective exchange rate. Findings also report that there is no significant evidence for factors such as interest rate and population to affect the general price levels in developing countries.
\end{abstract}

Keywords: Inflation; Panel Approach; Developing Countries; Developed Countries

\section{INTRODUCTION}

¿ nflation has become a global phenomenon over the last three decades. Since the 1970s, the episode of high world-wide inflation has made economists to further study this trend. Host number of economists has investigated different aspects of inflation. The average inflation in the world recorded the highest rates during the 1980s and 1990s periods for about 16 percent and 15 percent, respectively. While the industrial countries recorded the highest inflation rates during the period of 1970s with about 9 percent, the average inflation for emerging and developing countries recorded the highest level during the 1980s for around 37 percent in average. Differences in levels of inflation across the world are resulted from inflation determinants in each region. While the period of 1970s experienced the dramatic increase in price levels, the period of 1990s attracted the highest price level overall. Sources of inflation worldwide are different from time to time. This paper attempts to shed some light on the determinants of inflation across large sample of countries in the world.

There are many considerations used in the literature to investigate sources of inflation. Importantly, demand and supply sides as well as spillovers of external sources have been broadly used to investigate determinants of inflation empirically. Studies have focused on the country specific determinants of inflation using the traditional sources of inflation. These studies include Mio and Higo (1999) for Japan, Khan and Schimmelpfennig (2006) for Pakistan, Durevall and Ndung'u (2001) in case of Kenya, Metin (1995) for EMU. Inflation literature has also employed different techniques to study the inflation across countries. Juselius (1992) uses factors of interest rate and exchange rate to study the spillover effect on inflation for the case of Denmark. Alfaro (2005) uses a panel approach to investigate the relationship between openness and inflation across large sample of countries.

In this study, we investigate the main sources of inflation across developed and developing countries. Studying such a case is important for several aspects. First, this study takes into account, and shows, differences between sources of inflation in developed and developing countries using a large data sample starting from 1970 to 2007. Second, adopting the theoretical model used by Bawumia (2002), Rutasitara (2004), and Korsu (2010), we modify the theoretical model to incorporate the demand side effect on inflation, the supply side effect, the monetary effect, and the external factor. In addition, the sources of inflation are estimated using random effects. Applying 
such technique may help creating a common constant term and an error term that take into account differences between the country intercept and the overall intercept of the model. As a result such technique leads for the possibility for stochasticity of countries differences. Furthermore, although most studies in inflation sources have focused on some aspects affecting inflation than others, this study gathers the most consistent determinants of inflation across these previous studies.

According to this study, we use a panel model with a random effect. We test predictions of the model using yearly data over the period 1970 to 2007. We estimate the effect on inflation based on four main aspects. These are demand side factors, monetary factors, an external factor, and a supply side factor. Results indicate that main determinants of inflation for developing countries are different than those for developed countries. We find that the main determinants of inflation for developed countries are government spending, money supply growth, world oil prices, interest rate, nominal effective exchange rate, and population. Whereas, sources of inflation for developing countries are estimated to include government spending, money supply growth, world oil prices, and the nominal effective exchange rate.

This paper is organized as follows. Section II contains a brief survey of the relevant literature. Section III shows an overview on the main determinants of inflation and their expected effects on inflation. In section IV, the methodology and model specification used in the study are explained. Data are provided in section V. The empirical results are explained in section VI. The conclusion and policy implications are provided in section VII.

\section{LITERATURE REVIEW}

There are host of studies that have investigated the determinant of inflation. A study by De Brouwer and Ericsson (1998) investigates the inflation process in Australia by using the mark-up model which presents the supply side factors. In another study, Juselius (1992) finds a strong dependence of Danish prices on West Germany price level by examining the long run foreign transmission effects. Juselius (1992) shows that long run foreign transmission depends on the foreign or external factors of inflation. On the other hand, some researchers have found country-specific factors to influence inflation; these include, for instant, Mio and Higo (1999) in the case of Japan and Durevall and Ndung'u (2001) for Kenya.

Wang and Wen (2006) investigate the short-run inflation dynamics and the output across countries using eighteen developed countries. They find a significant average correlation of inflation across these countries. Darrat (1985) investigates the relationship between money and inflation in three developing countries. He finds that a high inflation is associated with a low real income growth and a high money supply.

Al-Raisi and Pattanaik (2003) investigate the impact of pass-through of exchange rate on Omani general price level. They find partial CPI responses to changes in the nominal effective exchange rate (NEER). ${ }^{1}$ Al-Mutari (1995) examines the influence of money supply, government expenditure, and import prices on inflation in Kuwait using the VAR model. He finds a role of government expenditure in Kuwait. His findings report a smaller effect of the import prices and money supply in explaining fluctuations in price level in Kuwait.

\section{OVERVIEW ON INFLATION DETERMINANTS}

This paper investigates the determinants of inflation across countries. There are host of studies that have investigated the determinants of inflation. The factors used to influence the inflation in this paper are extracted from previous studies. According to these studies, the general sources of inflation have been classified into four main aspects. These include the demand side factors, monetary factors, the external factor, and the supply side factor.

If the causes of inflation are from the demand side, then this source of inflation is specified to be demand pull inflation phenomena. Most studies have used the government spending to capture the demand for goods and services at the economy. Therefore, a high government spending leads to a higher inflation rate. This is through a

\footnotetext{
1 Specifically, the study by Al-Raisi and Pattanaik (2003) finds that a 10 percent depreciation in the Omani nominal effective
} exchange rate causes a rise of 0.4 percent in the consumer price index of Oman. 
higher demand for goods and services at the economy. The other factor that might be classified to a demand side factor is the number of population at the country. The more the number of the population at the economy leads to a higher demand and, eventually, consumption of goods and services at the economy. Higher private demand by consumers leads to push aggregate demand of the country beyond the production available at the economy. As a result, the inflation rate accelerates because of higher demand at the economy.

The second aspect involves monetary factors. The monetary side consists of two factors. Based on previous literatures, we use the growth of money supply and the interest rate to capture the effect of monetary side on inflation. Based on the quantity theory of money, there is direct relationship between money growth and inflation. High inflation is associated with more flows of money supply. On the other hand, there is a negative relationship between the interest rate and inflation. This is as the decrease in interest rate indicates a low cost of borrowing, therefore encouraging too much of borrowing. Therefore, low levels of interest rate lead to higher inflation rates.

According to the previous literature, the external factor is specified by the volatility of exchange rates between the country and its main trading partners. Studies use the nominal effective exchange rate (NEER) to proxy for the exchange rate volatility. The NEER is calculated as the foreign currency price per local currency. Therefore, the decrease in NEER represents a depreciation of the local currency versus main currencies. Hence, people would pay more for foreign purchases leading the inflation rate to accelerate. This source of inflation is also called an imported inflation.

On the supply side factor, the price of crude oil is used as an indicator for the cost of production at the economy. Since oil price is a part of input price, then higher oil prices add more cost in producing goods at the economy, resulting in reducing the supply. This type of inflation is called cost push inflation.

\section{METHODOLOGY AND MODEL SPECIFICATION}

While most studies have investigated the determinants of inflation using time series methodology, in this paper we examine the determinants of inflation through panel data analysis. The empirical model for inflation determinants is tested two times. The model first is tested using the whole data sample including developed and developing countries. Then, the model is examined using developed countries and developing countries separately.

The theoretical model of inflation determinants is based on modeling the price level. We follow the work of Bawumia (2002), Rutasitara (2004), and Korsu (2010) at which the model can be explained by the weight of the overall price level $\left(P_{t}\right)$ that contains the average price of tradable goods $\left(P_{t}^{T}\right)$ and of nontradable goods $\left(P_{t}^{N T}\right):^{2}$

$$
\log \left(P_{t}\right)=\gamma \log \left(P_{t}^{T}\right)+(1-\gamma) \log \left(P_{t}^{N T}\right)
$$

Where $0<\gamma<1$.

From the equation above, the average price of tradable goods $\left(P_{t}^{T}\right)$ is written to be a function of the foreign prices $\left(P_{t}^{F}\right)$ and the exchange rate $\left(E X_{t}\right)$. Therefore, by the assumption of holding purchasing power parity, the average price of tradable goods $\left(P_{t}^{T}\right)$ can be written as:

$$
\log \left(P_{t}^{T}\right)=\log \left(E X_{t}\right)+\log \left(P_{t}^{F}\right)
$$

According to equation (2), any changes generated from the exchange rate or the foreign price lead to changes in the

\footnotetext{
${ }^{2}$ The model is also used by Ubide (1997) to investigate the determinants of inflation in Mozambique, Also a study by Laryea and Sumaila (2001) uses the estimated model to examine the determinants of in inflation in Tanzania.
} 
domestic tradable goods prices. We modify equation (2) to include oil prices. Oil prices $\left(P_{t}^{\text {oil }}\right)$ will affect the price of the tradable goods as the country should be involved in exporting or importing of oil. The Oil price can be used as an indicator for the cost of production at the economy. Therefore the equation above will be rewritten as follows:

$$
\log \left(P_{t}^{T}\right)=\log \left(E X_{t}\right)+\log \left(P_{t}^{F}\right)+\log \left(P_{t}^{\text {oil }}\right)
$$

Also assuming that the price of nontradable goods is determined domestically in the money market, then following Laryea and Sumaila (2001) the price of nontradable goods is verified by the equilibrium condition of money market. That is the real money supply (MS/P) should equal the real money demand (MD). Based on those assumptions, the price of nontradable goods can be written as follows:

$$
\log \left(P_{t}^{N T}\right)=\eta\left\{\log \left(M S_{t}\right)+\log \left(M D_{t}\right)\right\}
$$

Assuming the demand for nontradable goods varies subject to variation of the overall demand in the economy. The parameter $\eta$ represents the relationship between demand for the nontradable goods and overall demand in the economy. According to the quantity theory of money, the demand for money depends on income and cost of holding money. Since the interest rate represents the opportunity cost of borrowing, then the demand for money would rely also on income $\left(Y_{t}\right)$, and interest rate $\left(i_{t}\right)$ :

$$
\left(M D_{t}\right)=f\left\{\left(Y_{t}\right),\left(i_{t}\right)\right\}
$$

Modifying the above equation, we are looking for specifying the type of transaction in the economy either through government transaction or consumers at the economy. Therefore, we modify the above equation to extend the effect of income $\left(Y_{t}\right)$ to include the government spending $\left(\operatorname{Exp}_{t}\right)$ and the private consumption in the overall economy. Due to data availability for the private consumption especially in developing countries, we use a proxy for private consumption to include instead the number of population in the economy $\left(\operatorname{Pop}_{t}\right)$. The more the number of population at the economy is, the more the private demand for goods and services in the economy. Thus, equation (5) can be rewritten as follows:

$$
\left(M D_{t}\right)=f\left\{\left(\operatorname{Exp}_{t}\right),\left(\operatorname{Pop}_{t}\right),\left(i_{t}\right)\right\}
$$

Generally, re-specifying equation (1), the equation of price level can be expressed as follows:

$$
\left(P_{t}\right)=f\left\{\left(M_{t}\right),\left(E X_{t}\right),\left(P_{t}^{F}\right),\left(P_{t}^{\text {oil }}\right),\left(\operatorname{Exp}_{t}\right),\left(\operatorname{Pop}_{t}\right),\left(i_{t}\right)\right\}
$$

Since it is hard to specify a specific foreign price for each country specific, then we can proxy for the foreign price by using the nominal effective exchange rate to capture any exchange rate volatility between the country and its main trading partners. Therefore we use the nominal effective exchange rate to proxy for both exchange rate variable and forging price to avoid any endogeniety between the two variables.

Accordingly, the log-linearizing equation of number (7) can be expressed to explain the model of inflation determinants as below:

$$
\begin{aligned}
\log \left(\pi_{i}\right)_{t} & =\beta_{0}+\beta_{1} \log \left(\operatorname{Exp}_{i}\right)_{t}+\beta_{2} \log \left(M_{i}\right)_{t}+\beta_{3} \log \left(P^{\text {oil }}\right)_{t}+\beta_{4} \log \left(i_{i}\right)_{t} \\
& +\beta_{5} \log (\operatorname{NEEX})_{t}+\beta_{6} \log \left(\text { Pop }_{i}\right)_{t}+\lambda_{t}+\varepsilon_{i j t}
\end{aligned}
$$


where the inflation level $\left(\pi_{i}\right)$ at country $i$ is the dependent variable and is measured the consumer price index (CPI); $\operatorname{Exp}_{i}$ denotes the total government expenditure in billion US dollar; $M_{i}$ is the broad money growth measured in billion US dollar ; oil ${ }_{i}$ is the world crude oil price; $i_{i}$ is the interest rate measured by the discount rate; $N E E X_{i}$ represents the nominal effective exchange rate; $P O P_{i}$ represents the number of population measured in million in each country $i ; \lambda_{i}$ is country specific effects; and $\varepsilon_{i j}$ is an error term.

The above model is tested using random effects. The use of random effects technique helps controlling over the individual heterogeneity through assuming slope homogeneity allowing variation for individual effect. In other words, applying such technique may help creating a common constant term and an error term that take into account differences between the country intercept and the overall intercept of the model. Therefore this leads for the possibility for stochasticity of countries differences.

\section{DATA DESCRIPTION}

The data included in this study cover fifty nine countries throughout the period from 1970 to 2007 . The country dataset includes both developed and developing countries. Annual data for all variables are obtained from the IMF database (International Financial Statistics). All data are measured in billion U.S. dollars. The variable of the government spending is measured by government consumption expenditures. We use money plus quasi money as an indicator for money supply variable. The index of the nominal effective exchange rate is in average period. For the interest rate variable, we use the discount rate as a cost of lending, however we use market rate when the discount rate is not available for some countries. Oil price is measured by the international crude oil price. The number of population at the country is measured by a million of people and it is extracted from the IMF database (International Financial Statistics).

\section{EMPIRICAL RESULTS}

\subsection{Benchmark Results}

A summary of data is shown at Appendix A. Table 1 shows the results for the benchmark model using a pooled Ordinary Least Square (OLS) regression and random effects. The table represents the estimation across all countries used in the data sample. According to Table 1, most of the estimated coefficients for variables of inflation determinants are significant and show the expected sign. Based on the random effect technique, the coefficient of government expenditure is statistically significant at one percent level with a positive sign. This indicates that across the data sample the higher the spending by the government, the higher the inflation at the economy. While the coefficient of the growth of money supply turns out to be statistically significant at one percent level, it holds the opposite sign. Such coefficient indicates that the higher is the growth of money supply across countries, the lower is the inflation. The coefficient of oil price is statistically significant at one percent level with a positive sign. Meaning that high prices of world crude oil lead to rising in inflation levels. The impact of the interest rate on inflation reports the expected sign. The estimated coefficient of the interest rate turns to be highly significant at ten percent level. Based on the findings, low rate of interest rate leads to high level of inflation.

Similarly, the estimated coefficient of the nominal effective exchange rate is statistically significant at one percent level with a negative sign. This indicates that high inflation is associated with a low nominal effective exchange rate. Finally, the estimated variable of population is holding the expected positive sign. The estimated coefficient of the population is statistically significant at five percent level, suggesting that the more the number of population leads to more consumption of people at the economy which results in high inflation rate. 
Table 1. Benchmark Results; Pooled Sample

\begin{tabular}{|c|c|c|}
\hline Dependent variable: Log CPI & Pooled OLS & Random Effect \\
\hline Log Expenditure & $\begin{array}{c}0.0212 * * \\
(2.11)\end{array}$ & $\begin{array}{c}0.1398 * * * \\
(6.46)\end{array}$ \\
\hline Log Money Growth & $\begin{array}{c}-0.1424 * * * \\
(-4.30)\end{array}$ & $\begin{array}{c}-0.1365 * * * \\
(-5.42)\end{array}$ \\
\hline Log Oil & $\begin{array}{c}0.5339 * * * \\
(6.45)\end{array}$ & $\begin{array}{c}0.4842 * * * \\
(5.87)\end{array}$ \\
\hline Log Interest Rate & $\begin{array}{c}-0.2527 * * * \\
(-6.69)\end{array}$ & $\begin{array}{c}-0.1128^{*} \\
(-1.61)\end{array}$ \\
\hline Log Nominal Effective Exchange Rate & $\begin{array}{c}-1.0695 * * * \\
(-31.41) \\
\end{array}$ & $\begin{array}{c}-1.1584 * * * \\
(-15.71)\end{array}$ \\
\hline Log Population & $\begin{array}{c}-0.0150 \\
(-0.63) \\
\end{array}$ & $\begin{array}{c}0.1117 * * \\
(2.21) \\
\end{array}$ \\
\hline Obs. & 660 & 660 \\
\hline R2/ within R2 & 0.6799 & 0.6220 \\
\hline
\end{tabular}

Note: The table reports t-statistic in parentheses

* Significant at $10 \%$; * significant at $5 \%$; *** significant at $1 \%$

Robust standard errors (white test)

\subsection{Extended Results-Developed Countries}

In Table 2, the estimated model is tested using only developed countries. According to Table 2, the findings of random effect technique are robust to the findings of pooled OLS with the exception of population variable. The results of Table 2 using developed countries are similar to results shown in Table 1 using the whole data sample. This indicates that the main determinants of inflation at the developed countries include government spending, money supply growth, world oil prices, interest rate, nominal effective exchange rate, and population.

Table 2. Extended Results; Developed Countries

\begin{tabular}{|l|c|c|}
\hline \multicolumn{1}{|c|}{ Dependent variable: Log CPI } & Pooled OLS & Random Effect \\
\hline Log Expenditure & $0.0219^{* *}$ & $0.2914^{* * *}$ \\
& $(3.39)$ & $(11.18)$ \\
\hline Log Money Growth & $-0.0418^{* *}$ & $-0.0367 * *$ \\
& $(-2.15)$ & $(-2.43)$ \\
\hline Log Oil & $0.2507 * * *$ & $(4.56)$ \\
& $-0.2274 * * *$ & $(2.66)$ \\
\hline Log Interest Rate & $(-8.68)$ & $-0.1532^{* * *}$ \\
& $-0.1657 * *$ & $(-4.84)$ \\
\hline Log Nominal Effective Exchange Rate & $(-2.31)$ & $-0.4354^{* * *}$ \\
& -0.0109 & $(-4.12)$ \\
\hline Log Population & $(-0.60)$ & $0.1704 * *$ \\
& & $(2.05)$ \\
\hline & 305 & 305 \\
\hline Obs. & 0.3036 & 0.7449 \\
\hline R2/ within R2 & & \\
\hline
\end{tabular}

Note: The table reports t-statistic in parentheses

* Significant at $10 \%$;* significant at $5 \%$; *** significant at $1 \%$

Robust standard errors (white test)

Based on results, high inflation level is associated with high government spending, high oil prices, and high number of population. This suggests that when governments of developed countries spend more, the inflation level goes up as a result. The high world oil prices caused by high demand from, mostly, developed countries leads to high inflation in these countries resulted from rising in the cost of production. More growth of population at the 
developed countries is also considered to be one of main sources of inflation. A high growth of population leads to a high private consumption of goods and services which leads to demand pull inflation causing general prices to grow.

On the other hand, results show that high inflation levels at the developed countries is associated with low growth of money supply, low interest rate, and low nominal effective exchange rate. Finding for interest rate can be explained as low interest rate reflecting low cost of borrowing at the economy. Therefore low interest rate would discourage borrowers to borrow, leading inflation to slow down at the economy. For the nominal effective exchange rate, a high level of nominal effective exchange rate in the developed countries means an appreciation of their local currencies leading local currencies to be more expensive which results in low local inflation rates in developed countries.

Surprisingly, the estimated coefficient of the money growth turns out to be negatively related to the inflation rate. This suggests that the higher the growth of money in developed countries, the lower the inflation in these countries. This finding can be explained as countries in developed region mostly conduct interest rate targeting at which a specific short term interest rate is targeted by the monetary authority as in the USA. Therefore, when the central bank targets interest rate, it losses controlling over the money supply subject to changes in money demand. Thus, results explain that even though in cases where money supply is high levels, inflation rate is low.

\subsection{Extended Results-Developing Countries}

Results for developing countries are shown in Table 3. The estimated model is tested using only developing countries. According to Table 3, the results of random effect technique are found to be statistically significant with the exception of interest rate and population variables. The results of Table 3 using developing countries are different than those shown in Table 2 for developed countries. This indicates that the main determinants of inflation for developing countries are different than those for developed countries. The sources of inflation for developing countries are estimated to include government spending, money supply growth, world oil prices, and the nominal effective exchange rate.

Table 3. Extended Results; Developing Countries

\begin{tabular}{|l|c|c|}
\hline \multicolumn{1}{|c|}{ Dependent variable: Log CPI } & Pooled OLS & Random Effect \\
\hline Log Expenditure & -0.03109 & $0.1542^{* * *}$ \\
& $(-1.12)$ & $(3.31)$ \\
\hline Log Money Growth & $-0.2654^{* * *}$ & $-0.2352^{* * *}$ \\
& $(-4.36)$ & $0.6642^{* * *}$ \\
& $0.7155^{* * *}$ & $(5.02)$ \\
\hline Log Oil & $(5.42)$ & -0.0501 \\
& $-0.2909^{* * *}$ & $(-0.44)$ \\
\hline Log Interest Rate & $-1.0945^{* * *}$ & $-1.1678^{* * *}$ \\
& $(-24.95)$ & $(-15.68)$ \\
\hline Log Nominal Effective Exchange Rate & $0.0655^{*}$ & 0.0611 \\
& $(1.61)$ & $(1.10)$ \\
\hline Log Population & & 379 \\
\hline & 379 & \\
\hline Obs. & 0.6863 & \\
\hline R2/ within R2 & & \\
\hline Note: The ta & \\
\hline
\end{tabular}

Note: The table reports t-statistic in parentheses

* Significant at 10\%; ** significant at 5\%; *** significant at $1 \%$

Robust standard errors (white test)

According to the findings of Table 3, levels of inflation accelerate when there is a high government spending as well as high oil prices. This suggests that more spending by governments of developing countries leads to high inflation levels. Also, high world oil prices lead to high inflation levels. This is due to the fact that developing countries are mostly dependent on imports from developed countries, thus rising in the cost of production in developed countries leads to inflation in the developing countries as a result. 
On the other hand, results show that high inflation levels at the developing countries is associated with low growth of money supply, and low nominal effective exchange rate. For the nominal effective exchange rate, higher level of nominal effective exchange rate in the developed countries means an appreciation of their local currencies leading local currencies to be more expensive which results in lower local inflation rate in developed countries. The result of growth of money supply is inconsistent with the theory but consistent with results found for developed countries. An explanation for such result can be drown from the fact that even when growth of money supply is high, it can be the case that the inflation is in low levels. This is because of other factors that influence inflation in these countries such as government spending, world oil prices, and the nominal effective exchange rate.

\section{CONCLUDING REMARKS}

The study investigates the main sources of inflation across developed and developing countries. We use a panel model with random effects. Predictions of the model are tested using yearly data over the period 1970 to 2007. The estimated effect on inflation is examined based on four main aspects; these are demand side factors, monetary factors, an external factor, and a supply side factor. Findings indicate that main determinants of inflation at the developed countries are different than those for developing countries. For developed countries, the main sources of inflation include government spending, money supply growth, world oil prices, interest rate, nominal effective exchange rate, and population. Whereas the main sources of inflation for developing countries are government spending, world oil prices, and nominal effective exchange rate. The surprising finding of the money growth can be explained as the role of money at the economy whether in the case of developing countries or developed countries. Such result suggests that even though money supply is growing at the economy, it can be the case that inflation level is declining.

In addition to the empirical findings of the model tested, the results may be utilized by both monetary authorities and policy makers to help specifying the general economic policy in the country. A number of policy implications may be derived from the estimates obtained in the current paper. First of all, it seems that the inflation in the developed countries is engineered by all the main aspects influencing inflation; these are demand side factors (government spending, population), monetary factors (money growth, interest rate), supply side factor (oil prices), and external factors (nominal effective exchange rate). In addition, for developing countries the inflation is more stimulated by the demand side effect (government spending), the supply side (oil prices), as well as the external factor (nominal effective exchange rate) than the monetary variables. Furthermore, as a result this means that the inflation in developing countries is not really a monetary phenomenon. Thus, authorities in developing countries can control inflation by effectively using fiscal policy (through government expenditures), improving their trade position to not heavily be an importer dependent, and finally implementing the suitable exchange rate policy.

Regarding the developed countries, price developments in these countries are largely determined by the monetary variables, especially interest rate. Therefore, monetary policy can play an important role in controlling domestic inflation. Beside the monetary variables, other economic factors such as government spending, oil prices, private consumption (measured by population), and nominal effective exchange rate are suggested to affect the economic activities at developed countries and as a result domestic movements in prices. Furthermore, these factors appear to go hand in hand to influence domestic prices.

\section{AUTHOR INFORMATION}

Nayef N. Al-shammari, Ph.D. Currently, He is an Assistant Professor at the Department of Economics, college of Business Administration, Kuwait University. He holds a bachelor's degree in economics from Kuwait University, a master's degree in economics from the American University at Washington D.C, and a doctor of philosophy in economics from Syracuse University, NY. E-mail: alshammari@cba.edu.kw. Corresponding author.

Mohammed A. Al-Sabaey, MA. Currently, He is an Instructor at the Department of Economics, College of Business Studies, Public Authority for Applied Education and Training. He holds a bachelor's degree in economics from Kuwait University, a master's degree in economics from the Middle Tennessee State University, TN. E-mail: ma.alsabaey@paaet.edu.kw. 


\section{REFERENCES}

1. Alfaro, L. (2005). Inflation, openness, and exchange-rate regimes: the quest for short-term Commitment. Journal of Development Economics 77, pp. 229-249.

2. Al-Mutari, N. (1995). Examining the causes of inflation in Kuwait: an application of a vector autoregression Model. OPEC Review.

3. Al-Raisi , A. and S. Pattanaik. (2003). Pass-Through of Exchange Rate Changes to Domestic Prices in Oman. Occasional Paper, Central Bank of Oman, No. 1.

4. Bawumia, M. (2002). Monetary Growth, Exchange Rates and inflation in Ghana. The West African Journal of Monetary and Economic Integration, 2, pp. 71-88.

5. Darrat, A. (1985). The Monetary Explanation of inflation: The Experience of three Major OPEC Economy. Journal of Economics and Business 37, pp. 209-21.

6. De Brouwer,G. J. and N. Ericsson. (1998). Modeling Inflation in Australia. Journal of Business and Economic Statistics 16(4), pp. 433-49.

7. Durevall, D., and N. S. Ndung'u, (2001). A Dynamic Model of Inflation for Kenya 1974-1996. Journal of African Economies, 10 (1), pp. 91-124.

8. Juselius, K. (1992). Domestic and foreign effects on prices in an open economy: The case of Denmark. Journal of Policy Modeling, Elsevier 14(4), pp.401-28.

9. Khan, M. and A. Schimmelpfennig. (2006). Inflation in Pakistan: Money or Wheat?. SBP-Research Bulletin; 2(1)

10. Korsu, R. (2010). Fiscal Deficit and the External Sector Performance of Sierra Leone: A Simulation Approach. Journal of Economic and Monetary Integration; 9(1), pp. 51-73.

11. Laryea, S. and U. Sumaila. (2001). Determinants of inflation in Tanzania, Working paper. Bergen: Chr. Michelsen Institute, No. 12.

12. Metin, K. (1995). An Integrated Analysis of Turkish Inflation, Oxford Bulletin of Economics and Statistics, 57, pp. 513-531.

13. Mio, H. and Masahiro H. (1999). Underlying Inflation and the Distribution of Price Change: Evidence from the Japanese Trimmed-Mean CPI. Bank of Japan, Economic and Monetary Studies, 17(1), pp. 103-132.

14. Ndanshau, Michael O.A . (2010). Money and other determinants of inflation: the case of Tanzania, Indian Journal of Economics and Business; 9(3).

15. Ubide, A. (1997). Determinants of Inflation in Mozambique. Working paper, International Monetary Fund, No. 145.

16. Rutasitara, L. (2004) . Exchange Rate Regimes and Inflation in Tanzania. African Economic Research Consortium, Nairobi, AERC Research Paper 138.

17. Wang, P. and Y. Wen. (2006) . Inflation Dynamics: A Cross-Country Investigation. Working paper Federal Reserve Bank of St. Louis, No. 076. 
APPENDIX A: DESCRIPTIVE STATISTICS

\begin{tabular}{|l|c|c|c|c|c|}
\hline \multicolumn{1}{|c|}{ Variable } & Obs. & Mean & Std. Dev. & Min & Max \\
\hline Log CPI & 660 & 3.856853 & 1.30712 & -4.60517 & 4.919908 \\
\hline Log Money Growth & 519 & -2.158648 & 1.000262 & -6.620698 & 0.3353095 \\
\hline Log of Oil & 722 & 2.907022 & 0.688904 & 1.22083 & 4.162003 \\
\hline Log Population & 703 & 3.625785 & 1.587704 & 1.036737 & 7.186038 \\
\hline Log Expenditure & 697 & 4.575522 & 2.992380 & -0.2194006 & 16.81162 \\
\hline Log Discount & 596 & 1.771610 & 0.786927 & -2.302585 & 4.084799 \\
\hline $\begin{array}{l}\text { Log Nominal Effective } \\
\text { Exchange Rate }\end{array}$ & 512 & 4.599949 & 0.3564176 & 3.138099 & 6.674726 \\
\hline
\end{tabular}

